T. Vakhonieva, Dr of Law, Prof.

Taras Shevchenko National University of Kyiv, Kyiv, Ukraine

\title{
MAINTENANCE OF WORK ACTIVITIES ON A PROFESSIONAL BASIS AS A FUNCTION OF LABOR LAW
}

The article examines the main components of professional activity as a sign of labour relations. The importance of labour law and its mechanisms in the field of maintaining the appropriate professional level of employees in performing their duties is established. The connection of labour law norms with the norms of education legislation is substantiated, the importance of professional standards in its formation is determined. Maintaining the proper professional qualification level of employees is recognized as a special and important function of labour law, which leads to the expansion of the subject of labour law and the emergence of new institutions of labour law. The result of proper provision of labour law to perform work on a professional basis is to obtain a quality material and intellectual product for a wide range of consumers.

Key words: professionalism, profession, position, qualification, professional standard, professional qualities, function of labour law, competence.

Bulletin of Taras Shevchenko National University of Kyiv. Legal Studies, 2020; 3 (114): 13-16

Удк: 349.2

DOI: https:doi.org/10.17721/1728-2195/2020/5.115-3
ISSN 1728-2195

C) Taras Shevchenko National University of Kyiv

Publishing center "Kyiv University", 2020

С. Венедіктов, д-р юрид. наук, проф. ORCID ID 0000-0002-0967-5085

Київський національний університет імені Тараса Шевченка, Київ, Україна

\section{ЩОДО РАТИФІКАЦІЇ УКРАЇНОЮ КОНВЕНЦІЇ МОП № 190 ПРО ВИКОРІНЕННЯ НАСИЛЬСТВА ТА ДОМАГАНЬ У СФЕРІ ПРАЦІ}

Досліджено ключові положення Конвенції МОП № 190 та проведено аналіз нормативно-правових актів України, щодо питань протидії насильству та домаганням у сфері праці. З'ясовано, що нині на рівні національного законодавства сформовано належне підґрунтя для подальшої ратифікації Україною Конвенції № 190. Зазначене зумовлено, передусім, прийняттям 2017 р. Закону України "Про запобігання та протидію домашньому насильству", яким запроваджено важливі зміни до чинних нормативно-правових актів у частині визначення понять "сексуальні домагання" та "насильст80 за ознакою статі", а також механізми боротьби з ними.

Установлено, що ратифікація Україною Конвенції МОП № 190 в подальшому дозволила би: чітко визначити мандат Державної служби України з питань праці щодо здійснення державного контролю за дотриманням роботодавиями законодавства про протидію насильству та домаганням, а також механізмів захисту від віктимізації або помсти щодо скаржників, жертв, свідків і викривачів; закріпити на законодавчому рівні право працівника відмовитися від дорученої роботи при настанні ситуації, що може представляти загрозу для його життя, здоров'я або безпеки через насильство та домагання; врахувати насильство і домагання, а також відповідні психосоціальні ризики в межах національної системи управління охороною праці; врегулювати питання прийняття на локальному рівні політики щодо насильства та домаеань на робочому місці; передбачити відповідні заходи, спрямовані на пом'якшення наслідків побутового насильства для сфери праці.

Ключові слова: Міжнародна організація праці, стандарти МОП, сфера праці, насильство, домагання, ратифікація конвенцій МОП.

ВСтуп. Стандарти Міжнародної організації праці (далі - МОП) традиційно займають одне із ключових місць серед джерел національного трудового права. Зумовлено це передусім членством нашої держави, починаючи з 1954 р., у цій одній із найстаріших і найавторитетніших міжнародних організацій, якій у минулому році виповнилося 100 років. На цей час Україна ратифікувала 71 конвенцію МОП, зокрема, усі існуючі фундаментальні та пріоритетні конвенції. Мабуть завдяки наведеній обставині, Кодекс законів про працю України (далі - КЗпП України), який фрактично є віддзеркаленням ратифікованих конвенцій МОП, попри свою майже 50-річну історію, ще й досі продовжує бути актуальним у питаннях регулювання трудових відносин.

На останній сесії Міжнародної конференції праці, що проходила в липні 2019 р., були прийняті Конвенція № 190 та Рекомендація № 206 про викорінення насильства та домагань у сфері праці. Появу наведених двох стандартів МОП слід назвати дуже важливим кроком у бік подальшого розвитку трудового права. Адже їхні положення фактично розширюють сферу застосування норм трудового права, охоплюючи нею відносини протидії насильству та домаганням, наголошуючи при цьому, що наведені явища можуть являти собою порушення прав людини або призводити до зловживань, $є$ загрозою принципу рівності можливостей, неприйнятні та несумісні з гідною працею.
Станом на сьогодні Конвенцію № 190 про викорінення насильства та домагань у сфері праці від 2019 р. (далі - Конвенція № 190) ратифікували лише дві країни - Фіджі та Уругвай [1]. Наведену обставину жодним чином не треба розглядати як приклад неефективності її положень. Слід зазначити, що ратифікація конвенцій МОП є достатньо складним процесом, який передбачає дотримання великої кількості формальних процедур та етапів, а тому він не може бути швидко реалізованим у часі. Тому, без сумніву, у подальшому, кількість держав, які ратифікували Конвенцію № 190, збільшуватиметься. Наприклад, ще навесні 2020 р. такі країни, як Аргентина, Іспанія та Фінляндія офіційно висловили своє зобов'язання ратифрікувати наведену Конвенцію [2].

ВИКЛАД ОСНОВНОГО МАТЕРІАЛУ. АктУаЛЬність запровадження Україною сучасних стандартів МОП не викликає сумніву. Свого часу І. Я. Кисельов доречно підкреслював, що МОП є тією організацією, яка спеціально утворена для вирішення завдань, пов'язаних із працею, та $€$ головним центром міжнародної нормативної діяльності з питань праці. МОП має статус спеціалізованої установи ООН, пов'язаної з нею спеціальною домовленістю. Ця домовленість визнала за МОП основну відповідальність за діяльність у сфері розв'язання міжнародних трудових і соціальних проблем [3, с. 457]. Норми конвенцій МОП відіграють важливе значення у розв'язанні проблеми уніфрікації норм трудового права різних країн [4, с. 471]. Повністю погоджуючись із наве- 
деними позиціями науковців, підкреслимо, що акти МОП являють собою баланс інтересів працівників, роботодавців та урядів, які до того ж пройшли належне випробування часом і практикою застосування. Не є винятком у цьому випадку й Конвенція № 190, ратифрікація якої Україною сприяла б не тільки посиленню її міжнародного статусу як соціальної держави, але і дозволила б покращити національні механізми боротьби з насильством і домаганнями у трудових правовідносинах.

Серед ключових особливостей Конвенції № 190 [5] слід виділити такі:

1. Закріплення визначення поняття "насильство і домагання" у ссрері праці, під яким розуміють ряд неприйнятних форм поведінки і практики або їх загроза, метою, результатом або можливим наслідком яких $є$ заподіяння фрізичної, психологічної, сексуальної або економічної шкоди, включаючи гендерне насильство і домагання.

2. Конкретизація повноважень інспекції праці в частині виявлення випадків насильства та домагань на робочому місці, а також розроблення відповідних програм підготовки та навчання інспекторів праці з гендерних питань із метою виявлення й усунення проявів насильства і домагань у сфері праці, зокрема психосоціальних факторів небезпеки і ризиків, гендерного насильства та домагань і дискримінації щодо особливих груп працівників.

3. Сприяння розробленню за участю трудових колективів спеціальних локальних актів - політик на робочому місці, що стосується насильства та домагань.

4. Врахування насильства і домагань, а також відповідних психосоціальних ризиків, в межах національної системи управління охороною праці.

5. Гарантування працівникам, що постраждали від насильства і домагання, вільного доступу до: процедур подачі скарг і розслідувань; механізмів урегулювання спорів безпосередньо на робочому місці та поза його межами; органів судової влади; засобів захисту від віктимізації; правових, соціальних, медичних та адміністративних заходів підтримки.

6. Забезпечення належного захисту приватного життя та конфіденційності осіб, що постраждали від насильства і домагання у сфрері праці.

7. Гарантування права працівникам залишати робочі місця, якщо вони мають достатньо вагомі підстави вважати, що умови їхньої праці створюють назріваючу і серйозну небезпеку для їхнього життя або здоров'я через насильство і домагання.

8. Запровадження відповідних заходів, спрямованих на пом'якшення наслідків побутового насильства для сорери праці.

Звертаючись до національного законодавства про працю слід констатувати, що воно не конкретизує в своїх положеннях питання, що стосуються протидії насильству та домаганням. Але, зазначену обставину не слід сприймати як таку, що вказує на відсутність відповідних гарантій для працівників, що стикаються 3 наведеними негативними явищами. Адже відповідно до ст. 2 Рекомендації № 206 про викорінення насильства та домагань у сфрері праці від 2019 р., реалізація положень Конвенції № 190 здійснюється за допомогою трудового законодавства, законодавства у сфері зайнятості, законодавства про охорону праці, законодавства про рівність і недопущення дискримінації, а також кримінального законодавства у відповідних випадках [6].

2017 р. Верховною Радою України прийнято Закон України "Про запобігання та протидію домашньому насильству". Зазначеним Законом, крім визначення організаційно-правових засад та напрямів реалізації держа- вної політики у сфрері запобігання та протидії домашньому насильству, також запроваджено зміни до існуючих нормативно-правових актів. Серед таких актів окремо слід виділити Закон України "Про забезпечення рівних прав і можливостей жінок і чоловіків", в якому визначено поняття "сексуальні домагання" та "насильство за ознакою статі", а також передбачено механізми боротьби із зазначеними явищами. Причому, відповідно до преамбули Закону, його метою $є$ досягнення паритетного становища жінок і чоловіків у всіх сферах життєдіяльності суспільства шляхом правового забезпечення рівних прав і можливостей жінок і чоловіків, ліквідації дискримінації за ознакою статі та застосування спеціальних тимчасових заходів, спрямованих на усунення дисбалансу між можливостями жінок і чоловіків реалізовувати рівні права, надані їм Конституцією і законами України [7]. Таким чином, положення Закону України "Про забезпечення рівних прав і можливостей жінок і чоловіків" поширюється зокрема й на відносини, що існують у сфрері праці.

Безпосередньо нормами Закону України "Про забезпечення рівних прав та можливостей жінок і чоловіків" визначено право постраждалої особи на: дієвий, ефективний і невідкладний захист у разі вчинення насильства; звернення особисто або через свого представника до суб'єктів, що здійснюють заходи у сфері запобігання та протидії насильству за ознакою статі; отримання повної та вичерпної інформації від суб'єктів, що здійснюють заходи у сфері запобігання та протидії насильству за ознакою статі, щодо своїх прав, заходів і соціальних послуг, якими вони можуть скористатися; безоплатне отримання відповідно до законодавства медичної, соціальної та психологічної допомоги, інших соціальних послуг; безоплатну правову допомогу; повагу до честі та гідності, уважне та гуманне ставлення 3 боку суб'єктів, що здійснюють заходи у сфері запобігання та протидії насильству за ознакою статі; конфіденційність інфоормації особистого характеру; відшкодування матеріальних збитків і моральної шкоди, завданих унаслідок дискримінації за ознакою статі, сексуальних домагань чи інших актів насильства за ознакою статі. Крім того, Законом установлено обов'язок роботодавця вживати належних заходів щодо створення безпечних для життя і здоров'я умов праці, а також щодо унеможливлення та захисту від випадків сексуальних домагань та інших проявів насильства за ознакою статі.

Положення Закону України "Про забезпечення рівних прав та можливостей жінок і чоловіків" також закріплюють певні імперативні вимоги до змісту колективних договорів в частині: покладання обов'язків уповноваженого з ґендерних питань - радника керівника підприємства установи й організації, їх структурних підрозділів на одного $з$ працівників на громадських засадах; комплектування кадрами і просування працівників по роботі з дотриманням принципу надання переваги особі тієї статі, щодо якої в них існує дисбаланс; усунення нерівності за її наявності в оплаті праці жінок і чоловіків як у різних галузях господарства, так і в одній галузі на базі загального соціального нормативу оплати праці в бюджетній та інших сорерах, а також на основі професійної підготовки (перепідготовки) кадрів. До речі, на початку 2020 р. Міністерством соціальної політики України прийнято Методичні рекомендації щодо внесення до колективних договорів та угод положень, спрямованих на забезпечення рівних прав і можливостей жінок і чоловіків у трудових відносинах. Підпункт 4.4. наведених Методичних рекомендацій враховує також і компонент, 
пов'язаний із домаганням і тиском на робочому місці (переслідуванням, мобінгом) [8].

Звертаючись до відповідальності особи за вчинення насильства та домагання у сфері праці, слід зазначити, що вона передбачена передусім положеннями кримінального й адміністративного законодавства. Так, ст. 173-2 Кодексу України про адміністративні правопорушення встановлює адміністративну відповідальність за вчинення насильства за ознакою статі, тобто будь-яких діянь (дій або бездіяльності) фрізичного, психологічного чи економічного характеру (застосування насильства, що не спричинило тілесних ушкоджень, погрози, образи чи переслідування, позбавлення житла, їжі, одягу, іншого майна або коштів, на які потерпілий має передбачене законом право, тощо), унаслідок чого могла бути чи була завдана шкода фрізичному або психічному здоров'ю потерпілого [9]. У свою чергу, ст. 153, 154 Кримінального кодексу України передбачають кримінальну відповідальність вчинення сексуального насильства (будьякі насильницькі дії сексуального характеру, не пов'язані із проникненням в тіло іншої особи, без добровільної згоди потерпілої особи) та примушування особи без їі добровільної згоди до здійснення акту сексуального характеру з особою, від якої потерпіла особа, яка матеріально або службово залежна [10].

Порівняльний аналіз положень національного законодавства та Конвенції № 190 дозволяє звернути увагу також і на існуючі пробіли правового регулювання протидії насильству та домаганням в Україні. Так, наприклад, Положення про Державну службу України з питань праці, затверджене постановою Кабінету Міністрів України від 11.02.2015 № 96 [11], не конкретизує повноваження наведеної служби щодо здійснення державного контролю за дотриманням роботодавцями законодавства про протидію насильству та домаганням у сорері праці. Зазначене стосується й відсутності чітких вимог до програм підготовки та навчання інспекторів праці з гендерних питань із метою виявлення й усунення проявів насильства і домагань у сфрері праці, зокрема психосоціальних фракторів небезпеки і ризиків, гендерного насильства та домагань і дискримінації щодо особливих груп працівників.

Незважаючи на те, що ч. 5 ст. 153 КЗпП України надає працівникові право відмовитись від дорученої роботи, якщо створилася виробнича ситуація, небезпечна для його життя чи здоров'я або людей, які його оточують, і навколишнього середовища [12], Кодекс окремо не визначає такого права у випадку настання ситуації, зумовленої насильством і домаганням. Крім того, КЗпП України не враховує насильство і домагання, а також відповідні психосоціальні ризики, у межах національної системи управління охороною праці.

Звертаючись до проблематики запровадження на локальному рівні політик щодо насильства та домагань на робочому місці, доречно навести положення Національного плану дій із виконання рекомендацій, викладених у заключних зауваженнях Комітету ООН із ліквідації дискримінації щодо жінок до восьмої періодичної доповіді України про виконання Конвенції про ліквідацію всіх форм дискримінації щодо жінок на період до 2021 р. Пункт 41 наведеного Національного плану передбачає розроблення рекомендацій щодо внесення в локальні акти роботодавців норм стосовно недопущення сексуальних домагань на робочому місці та реагування на них [13]. Слід констатувати, що Методичні рекомендації щодо внесення до колективних договорів та угод положень, спрямованих на забезпечення рівних прав і можливостей жінок і чоловіків у трудових відносинах [8], не повною мірою вирішують наведене питання. Але, незважаючи на зазначену обставину, серед роботодавців вже простежується стійка тенденція щодо самостійного запровадження політик щодо насильства та домагань на робочому місці. Як приклади у цьому випадку можна навести Політику попередження і боротьби із сексуальними домаганнями в Національному університеті "Києво-Могилянська академія" [14] та Положення про політику попередження і боротьби із сексуальними домаганнями у Національному технічному університеті "Дніпровська політехніка" [15].

Слід також зазначити, що національне законодавство не містить чітких положень стосовно розгляду скарг на насильство та домагання та процедур їх розслідування на рівні робочих місць. Безперечно, ст. 221-230 КЗпП України надають право працівникам оскаржувати протиправні дії роботодавців у комісії з трудових спорів, які можуть створюватися на підприємствах. Але, в умовах XXI сторіччя наведена комісія вже не $€$ тим ефективним органом досудового вирішення трудових спорів, яким вона вважалася за часів запровадження Кодексу. Ще одним недоліком КЗпП України слід назвати відсутність чітких механізмів захисту від віктимізації або помсти щодо скаржників, жертв, свідків і викривачів.

Незважаючи на достатньо комплексне врегулювання в Законі України "Про запобігання та протидію домашньому насильству" питань, що стосуються надання допомоги особам, постраждалим від домашнього насильства, зазначений законодавчий акт не закріплює у своїх положеннях відповідні заходи, спрямовані на пом'якшення наслідків побутового насильства для сфери праці. У свою чергу, серед таких заходів Рекомендація № 206 про викорінення насильства та домагань у сфері праці від 2019 р. виділяє такі: надання відпусток жертвам побутового насильства; надання жертвам переслідувань і побутового насильства гнучкого графіку роботи; тимчасовий захист жертв побутового насильства від звільнення [6].

вИСновкИ. Підсумовуючи все викладене, зазначимо, що нині в Україні сформовано належне підґрунтя для ратифікації Конвенції № 190. Причому визнання наведеної Конвенції юридично обов'язковою для нашої держави дозволило би в подальшому усунути ряд існуючих пробілів правового регулювання, що стосуються протидії насильству та домаганням у сфері праці. До таких пробілів, передусім, слід віднести: відсутність чіткого мандата Державної служби України з питань праці щодо здійснення державного контролю за дотриманням роботодавцями законодавства про протидію насильству та домаганням, а також механізмів захисту від віктимізації або помсти щодо скаржників, жертв, свідків та викривачів; відсутність чіткої норми, яка надавала би право працівнику відмовитись від дорученої роботи за настання ситуації, що може представляти загрозу для його життя, здоров'я або безпеки через насильство та домагання; неврахування насильства i домагань, а також відповідних психосоціальних ризиків у межах національної системи управління охороною праці; відсутність норм, які б урегульовували питання прийняття на локальному рівні політик щодо насильства та домагань на робочому місці, а також запроваджували відповідні заходи, спрямовані на пом'якшення наслідків побутового насильства для сфери праці.

Список використаних джерел

1. Ratifications of C190 - Violence and Harassment Convention, 2019 (No. 190). URL: https://www.ilo.org/dyn/normlex/en/f?p=1000:11300:0:: NO:11300:P11300_INSTRUMENT_ID:3999810 (дата звернення 16.09.2020). 
2. ILO welcomes commitments to ratify Convention on violence and harassment URL: https://www ilo.org/global/about-the-ilo/newsroom/news/ WCMS_737414/lang--en/index.htm (дата звернення 16.09.2020).

3. Киселев И. Я. Сравнительное и международное трудовое право : учебник для вузов / И. Я. Киселев. - М. : Дело, 1999. - 728 с.

4. Курс порівняльного трудового права : підручник у 2 т. / М. І. Іншин, А. Р. Мацюк, А. М. Соцький, В.І. Щербина; за ред. акад. А. Р. Мацюка. - 2-ге вид., змін. і доп. - Х. : Діса плюс, 2015. - 1056 с.

5. Violence and Harassment Convention, 2019 (No. 190). URL: https://www.ilo.org/dyn/normlex/en/f?p=NORMLEXPUB:12100:0::NO::P121 00_ILO_CODE:C190 (дата звернення 16.09.2020).

6. Violence and Harassment Recommendation, 2019 (No. 206). URL: https://www.ilo.org/dyn/normlex/en/f?p=NORMLEXPUB:12100:0::NO::P121 00 ILO CODE:R206 (дата звернення 16.09.2020).

7. Закон України "Про забезпечення рівних прав та можливостей жінок і чоловіків". URL: https://zakon.rada.gov.ua/laws/show/2866-15\#Text (дата звернення 16.09.2020).

8. Методичні рекомендації щодо внесення до колективних договорів та угод положень, спрямованих на забезпечення рівних прав і можливостей жінок та чоловіків у трудових відносинах, затверджені Наказом Міністерства соціальної політики України від 29.01.2020 р. № 56. URL: https://www.msp.gov.ua/documents/5627.html?PrintVersion (дата звернення 16.09.2020)

9. Кодекс України про адміністративні правопорушення. URL: : 16.09.2020)

10. Кримінальний кодекс України. URL: https://zakon.rada.gov.ua/ laws/show/2341-14\#n986 (дата звернення 15.09.2020).

11. Положення про Державну службу України з питань праці, затверджене постановою Кабінету Міністрів України від 11.02.2015 р. № 96. URL: https://zakon.rada.gov.ua/laws/show/96-2015-п\#Text (дата звернення 16.09.2020).

12. Кодекс законів про працю України. URL: https://zakon.rada.gov.ua/ laws/show/322-08\#Text (дата звернення 16.09.2020).

13. Національний план дій із виконання рекомендацій, викладених у заключних зауваженнях Комітету ООН із ліквідації дискримінації щодо жінок до восьмої періодичної доповіді України про виконання Конвенції про ліквідацію всіх форм дискримінації щодо жінок на період до 2021 року, затверджений розпорядженням Кабінету Міністрів України від 05.09.2018 № 634-p. URL: https://zakon.rada.gov.ua/laws/show/6342018-р\#Text (дата звернення 16.09.2020).

14. Політика попередження і боротьби із сексуальними домаганнями в Національному університеті "Києво-Могилянська академія". URL: https://www ukma edu.ua/index php/about-us/spilnoti/students-life/4213komitet-iz-poperedzhennia-i-borotby-iz-seksualnymy-domahanniamy (дата звернення 16.09.2020).

15. Положення про політику попередження і боротьби із сексуальнми домаганнями у Національному технічному університеті "Дніпровська політехніка". URL: http://www.nmu.org.ua/ua/content/activity/us_ documents/Shpcp.pdf (дата звернення 16.09.2020).

\section{References}

1. Ratifications of C190 - Violence and Harassment Convention, 2019 (No. 190). URL: https://www.ilo.org/dyn/normlex/en/f? $p=1000: 11300: 0$ :: NO:11300:P11300_INSTRUMENT_ID:3999810 (in English)

Sergii Venediktov, Dr of Law, Prof

Taras Shevchenko National University of Kyiv, Kyiv, Ukraine
2. ILO welcomes commitments to ratify Convention on violence and harassment URL: https://www ilo org/global/about-the-ilo/newsroom/news/ WCMS_737414/lang--en/index.htm (in English)

3. Kiselev I.YA. Sravnitel'noye i mezhdunarodnoye trudovoye pravo. Uchebnik dlya vuzov. M.: Delo, 1999. 728 c. (in Russian)

4. Kurs porivnyal'noho trudovoho prava : pidruchnyk u 2 tomakh / Inshyn M.I., Matsyuk A.R., Sots'kyy A.M., Shcherbyna V.I. / Za red. akad. A.R. Matsyuka. 2-he. vyd., zmin. i dop. Kharkiv : Disa plyus 2015. T. 1. 1056 s. (in Ukrainian)

5. Violence and Harassment Convention, 2019 (No. 190). URL: https://www.ilo.org/dyn/normlex/en/f?p=NORMLEXPUB:12100:0::NO::P121 00 ILO CODE:C190 (in English)

6. Violence and Harassment Recommendation, 2019 (No. 206). URL https://www.ilo.org/dyn/normlex/en/f?p=NORMLEXPUB:12100:0::NO::P121 00_ILO_CODE:R206 (in English)

7. Zakon Ukrayiny "Pro zabezpechennya rivnykh prav ta mozhlyvostey zhinok i cholovikiv". URL: https://zakon.rada.gov.ua/laws/show/286615\#Text (in Ukrainian)

8. Metodychni rekomendatsiyi shchodo vnesennya do kolektyvnykh dohovoriv ta uhod polozhen', spryamovanykh na zabezpechennya rivnykh prav i mozhlyvostey zhinok ta cholovikiv u trudovykh vidnosynakh, zatverdzheni Nakazom Ministerstva sotsial'noyi polityky Ukrayiny vid 29.01.2020 № 56. URL: https://www.msp.gov.ua/documents/5627.html? PrintVersion (in Ukrainian)

9. Kodeks Ukrayiny pro administratyvni pravoporushennya. URL: https://zakon.rada.gov.ua/laws/show/80731-10\#Text (in Ukrainian)

10. Kryminal'nyy kodeks Ukrayiny. URL: https://zakon.rada.gov.ua/ laws/show/2341-14\#n986 (дата звернення 15.09.2020).

11. Polozhennya pro Derzhavnu sluzhbu Ukrayiny z pytan' pratsi, zatverdzhene postanovoyu Kabinetu Ministriv Ukrayiny vid 11.02.2015 № 96. URL: https://zakon.rada.gov.ua/laws/show/96-2015-n\#Text (in Ukrainian).

12. Kodeks zakoniv pro pratsyu Ukrayiny. URL: https://zakon.rada.gov.ua/ laws/show/322-08\#Text (in Ukrainian)

13. Natsional'nyy plan diy z vykonannya rekomendatsiy, vykladenykh u zaklyuchnykh zauvazhennyakh Komitetu OON z likvidatsiyi dyskryminatsiyi shchodo zhinok do vos'moyi periodychnoyi dopovidi Ukrayiny pro vykonannya Konventsiyi pro likvidatsiyu vsikh form dyskryminatsiyi shchodo zhinok na period do 2021 roku, zatverdzhenyy rozporyadzhennyam Kabinetu Ministriv Ukrayiny vid 05.09.2018 № 634-r. URL: https://zakon.rada.gov.ua/laws/show/634-2018-p\#Text (in Ukrainian)

14. Polityka poperedzhennya i borot'by iz seksual'nymy domahannyamy $v$ Natsional'nomu universyteti "Kyyevo-Mohylyans'ka akademiya". URL: https://www.ukma.edu.ua/index.php/about-us/spilnoti/ students-life/4213-komitet-iz-poperedzhennia-i-borotby-iz-seksualnymydomahanniamy (in Ukrainian)

15. Polozhennya pro polityku poperedzhennya i borot'by iz seksual'nymy domahannyamy u Natsional'nomu tekhnichnomu universyteti "Dniprovs'ka politekhnika". URL: http://www.nmu.org.ua/ua/content/activity/ us documents/Shpcp.pdf (in Ukrainian)

Received: $16 / 09 / 2020$ Accepted: $29 / 10 / 2020$

\section{TOWARDS THE ISSUE ON RATIFICATION OF THE ILO VIOLENCE AND HARASSMENT CONVENTION NO. 190 BY UKRAINE}

The article provides a comparative analysis of the ILO Convention No. 190 and Ukrainian legislation concerning the issues of combating violence and harassment in the world of work.

ILO standards have traditionally been one of the key sources of national labour law. Conventions and recommendations of this organization represent a balance of interests of workers, employers and governments, which have also been properly tested both in time and in practice. ILO Convention No. 190 is not an exception in this case. Ratification of this Convention will not only strengthen the international status of Ukraine, but also improve national mechanisms to combat violence and harassment in labour relations. Among the key features of the ILO Convention No. 190 the following should be highlighted: providing a definition of "violence and harassment" in the world of work, specification of the powers of the labour inspectorate in terms of detecting cases of violence and harassment, adoption in consultation with employees a workplace policy on violence and harassment, ensuring easy access to appropriate and effective remedies and dispute resolution mechanisms, etc.

It has been established that Ukraine currently has a proper basis for ratification of ILO Convention No. 190. This is primarily due to the adoption in 2017 of the Law on Prevention and Counteraction to Domestic Violence, which introduced a number of important amendments to existing legislation in terms of enshrining at the regulatory level the concepts of "sexual harassment" and "gender-based violence", as well as mechanisms to combat them. The recognition of this Convention as legally binding for Ukraine would further eliminate a number of existing gaps in legal regulation relating to combating violence and harassment in the world of work. Such gaps include: the lack of a clear mandate from the State Labour Service to exercise state control over employers' compliance with anti-violence and harassment legislation, not taking into account violence and harassment and associated psychosocial risks in the management of occupational safety and health, lack of norms that would mitigate the impact of domestic violence in the world of work, etc.

Key words: International Labour Organization, ILO standards, world of work, violence, harassment, ratification of ILO conventions. 